\title{
TEACHER TRAINING: TECH SAVVY EDUCATOR COMMUNITY SERVICE FOR TEACHERS IN LEARNING CENTER, PPMT PARUNG
}

\author{
Stella Stefany ${ }^{1}$, Rijanto Purbojo ${ }^{2}$ \\ ${ }^{1}$ Universitas Pelita Harapan \\ ${ }^{2}$ Universitas Pelita Harapan
}

stella.stefany@gmail.com, Rijanto.purbojo@uph.edu

\begin{abstract}
Getting into Indonesia roadmap program "Making Indonesia 4.0", most of the sector industries have to divert their business into digital. Education as a stakeholder that support these main industries highlighted to put concern about digitizing their learning program. As a part of mission service, GKY Puri Indah nurturing scholar-teacher chain in a continuous program. They built several learning centers to facilitate students in improving their learning skills after school as a part of nurturing future leaders, especially for churches. Before assigned to churches, these graduates have to teach in the learning center for two years. The problem is how can these theological graduates play their role as a teacher. Teacher training systemic program that will be held continuously to educate these teachers. At the first session, conducted in two parts. First part highlighted topic about motivation, teaching, and learning, the second one, highlighted effective communication mediated by technology and approaches in using technology for managing the classroom. The method used in this community service is lecturing, discussion, and presentation as evaluation, divided into 4 phases: preparation, delivery, assessment, and evaluation. Result of this program is some motivated participants are needed to be enriched by consistent training at least twice in a year to improve their teaching skills and technology use in education.
\end{abstract}

Keywords: digital learning, online education, teacher training, digital classroom, technology

\section{INTRODUCTION}

Joko Widodo, as a president of Indonesia, has launched the program called "Making Indonesia 4.0" which interpreted as Industrial Revolution 4.0. The key to this revolution is digitalization. Government has targeted main sectors to be the main engine for this revolution: manufacturing and industry. Stakeholders of these main sectors need to be adjusted with the main road map of the government's policy. One of the most stakeholders is education. During these periods, Indonesia is still implementing the conventional method of learning from early childhood to higher education. Becker (2000) on her previous research, concluded that all educators used to start kind of teaching-learning process that would give opportunities to enhance theirselves in developing their skills in technology. The National Cent for Educational Statistics (1999) showed that less than $20 \%$ of teachers felt highly

$$
\text { Pendidikan }
$$


enthusiast integrate educational technology into teaching-learning process at their classroom. As time flies, Collier, Weinburgh, \& Rivera (2004) stated that a huge transformation have to be done in public education and teachers need to divert into digital movement in technology through educational technology process in their classrooms. Stefany (2017) in her research explained that in this era, students engaged with technology and increase the level of digital literacy among high school students. With continual increase in technology and characteristics of students today, millennials would have a shrinking, dependent and slothful mentality or even ready to face the global competition (Stefany \& Prihandini, 2017). Many schools have been adopting new methods to advance communication in teaching and learning process. By implementing new methods, there are opportunities for teachers as facilitators to improve their skills to use technology effectively as an effective part of their instruction (Guerrero, 2005).

Many institutions put their concern about improving the quality of life of a human being through the educational sector. As what GKY Puri Indah has been doing since ten years ago, they built several learning-centers (bimbingan belajar) to facilitate students improving their learning skills after school as a part of nurturing future leaders, especially for churches. Between 2007 and 2014, the percentage of the adult who identified as religiously unaffiliated increased from $16.1 \%$ to $22.8 \%$ and at the same period, the share of mainline Protestants moving from $18.1 \%$ to $14.7 \%$ (Lizardy-hajbi, 2018). GKY Puri Indah also concerned about this declining issue, as well as preparation of future leader in churches. Under the mission service, they are having their integrated educational programs by nurturing the internal human resources started by funding the scholarship of those who are willing to have higher education at the university level. The church found sponsors for these scholars and send them into the appoint theological school, as a part in nurturing future leader of the church. After graduating, these scholars need to fulfill the reciprocity program to be a teacher in several bimbingan belajar (bimbel) that they owned in all over Indonesia. The main concern is these teachers were graduated from Theological School, but they have assigned as a teacher for two years. That is the reason why GKY Puri Indah collaboratively with UPH to enhance the teaching, technology, and pedagogical skills of these graduates by conducting continuously training. When conducting the lesson program, as a trainer, it is necessary to identify the current condition of participants and initiative from the government to meet the need.

By improving their skills in teaching, technology, and pedagogical skills, it is important to have an integrated model to cover those three elements in learning planning path. To put on the technology as a medium, we believe, there will impact all elements in the communication process. As Channel Expansion Theory stated that every individuals earn extra experiences with a particular communication medium, the medium becomes richer for them (Carlson, J. R., \& Zmud, 1994). From the perspective of this theory, it will be more easy to conduct equivocal and interpersonally oriented in processing communication tasks. It surely will impact users to learn how to do process encoding and decoding the effective message by using a particular channel. This theory was extended to insert familiarity development with an interaction individual as second major factor (partner) which affect the richness or expressiveness of a medium that is used to run the communication process with extended potential factors as partner, conversational topic, and organizational experience (Carlson \& Zmud, 1999). This theory offered an antidote to the inconsistencies in media richness.

\section{METHOD}

Method divided into 4 phases: (1) preparation, (2) delivery, (3) assessment, (4) evaluation.

\section{Preparation}


Phase one will describe preparation before training held. It consists of brainstorming between the facilitators and chairman of the institution to identify the needs of participants. By having this meeting, facilitators can identify there were three main topics to be elaborated to enhance participants' skills: (1) planning, instruction, and technology, (2) Motivation, teaching and learning, (3) managing classroom. So, both parties decided to first check the participants' experiences through spreading out the pre-test, consist of (1) have you ever attend teacher training? (2) What is your motivation to teach? (3) Are you using the internet to find a reference in teaching materials searching? (4) How important is the internet for your teaching-learning process? (5) Do you educate your students in using the internet to find learning materials? (6) Do you know your homeclass students' teacher at school? (7) Do you know your students' parents? (8) Have you ever get into the boring situation to play your role as a teacher? (9) Have you ever given detention to your students? (10) In which condition, you feel very hard to teach? (11) What is the main challenge for you to play a role as a teacher in this institution? The result showed that most of the teachers haven't attended any teacher training, play the role as a teacher as it is, gets used to using the internet to find materials, did educate students to use the internet, and knowing and have a relation with the homeroom teachers and parents of their students. After recognizing all the brainstorming and pre-test result, facilitators decided to appoint Motivation, Teaching, and Learning, and Technology as the first topic to be delivered. Learning objectives of this training are (1) to remotivate teacher to their role as educator, (2) to educate teacher about pedagogy as teaching and learning process, (3) to use technology in enhancing teaching and learning process.

\section{Delivery}

On the training day, facilitator set the rundown as per shown in table 1 below:
Table 1. Rundown Training

\begin{tabular}{|c|l|}
\hline \multicolumn{1}{|c|}{ Time } & \multicolumn{1}{c|}{ Sub Topics } \\
\hline $09.00-10.30$ & $\begin{array}{l}\text { Motivation, } \\
\text { Teaching \& } \\
\text { Learning }\end{array}$ \\
\hline $10.30-12.00$ & Workshop \\
\hline $13.00-15.00$ & $\begin{array}{l}\text { Effective } \\
\text { communication } \\
\text { mediated by } \\
\text { technology } \\
\text { approaches in using } \\
\text { technology for } \\
\text { managing a } \\
\text { classroom }\end{array}$ \\
\hline $15.00-16.00$ & Study Case \\
\hline $16.00-18.00$ & Presentation \\
\hline
\end{tabular}

In the beginning, facilitators conduct a quiz by using kahoot platform as per seen on the link below: https://create.kahoot.it/details/survey-teachertraining/96b10563-d413-4a08-9403-1d57a9400467 as a medium to construct their image about technology using in teaching and learning process is quite fun. In this quiz, participants were being asked about how long they have been teaching in the learning center, majority of students' grade they have been teaching, their motivation to teach, their students' image about them as teachers, their future career plan.

After this quiz submitted, facilitator gets into the first materials about the perspective motivation that consists of behavioral, humanistic, cognitive, social aspects as shown in figure 1 below:

Figure 1. Material 1 


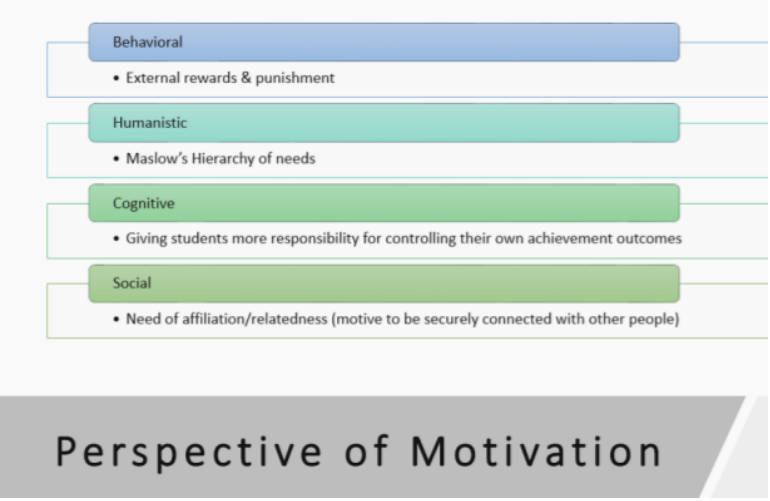

First, in the behavioral aspect, the facilitator explained about the differentiation about applying reward and punishment for students in managing classroom. How those things will be effective in the matter of discipline. Second, the humanistic aspect related to the hierarchy of needs. Participants were taught how to analyze human (generally) basic levels of needs, particularly, facilitators were educating them on how to fulfill each level of needs for their students to understand them better. Third, at the part of cognitive, participants learned about giving students more responsibility for controlling their achievement outcome. Fourth, talked about the connectedness between individual among society, what motives them to do a certain thing and its relatedness to others. Finally, this session was ended by a reflection question to be discussed in each team of participants as per shown in the figure below.

Figure 2. Reflection Part One
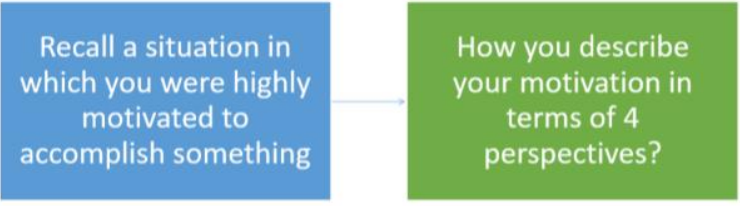

\section{Reflection}

Second materials discussed effective communication mediated by technology approaches in using technology for managing the classroom. Facilitators delivered materials about how to engage with students through effective communication, by elaborating component of communication, models of communication, verbal and non-verbal communication and how to communicate effectively as a teacher in the classroom setting. After that, getting into the technology session, facilitators taught each instruction to create activities based on the learning platform as kahoot. Figure 3 below is the platform that was taught as hands-on training materials where all participants have to make their account and test to be played together in the classroom.

Figure 3. Kahoot Display

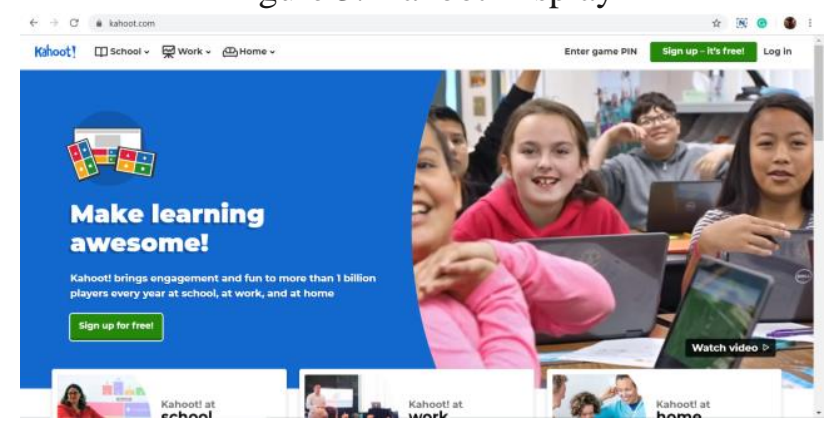

By the end of this session, participants had to present their materials as if they were teaching their students in the classroom.

\section{RESULT AND DISCUSSION}

In the first session about Motivation, Teaching \& Learning, facilitators were trying to explore their motivation to decide to play the role of a teacher in this learning center. We figured out that half of the participants play the role as a compensation for their scholarship, some of them consider as a temporary job and most of them have been firm with their role as a teacher. It was really good to use this moment to encourage these participants to nurture them with the positive sight to be an educator and how they can impact others' lives through their role. The highest result of the first reflection about recalling the situation in which they were highly motivated to accomplish something is the moment when they see progress as an improvement of their teaching contribution to students' understanding, indicated by

$$
\text { Pendidikan }
$$


their score improvement. The next question to be reflected interpreted very well with their current condition. They mentioned that they get used to give punishment instead of rewards to students, monitoring that some of the students are still in stage of completing their needs in lower stages, just about to start recognizing how to manage students to determine their own outcome target and at last, they believed that relationship in social aspect is quite important for them as facilitator to their partner (parents and homeroom teacher) and particularly to their students. This provides concludes that teacher with high motivation in using technology display opprotunities that promote attitudes of continual learning, challenged to take risk, and having deep curiosity. It is recognized by others as peers that finished the task first and a man to ask if they are in trouble with technology, they will also continue to find out answers for real cases they have to face and finding new ways to incorporate technology into teaching and learning. It confirmed the perspective of Swain and Pearson (2001).

We must educate all teachers and students to use the computer as a productivity tool as well as a tool for learning, research, networking, collaboration, telecommunications, and problem-solving. Always using drill-andpractice software does not allow students to participate in meaningful and engaging learning environments. (p. 12)

The second session discussed how to conduct effective communication mediated by technology, how technology can improve the learning process, especially in killing bored in students daily activities and improve their motivation to study. None of them have ever tried this platform (kahoot) as a medium in the learning-teaching process. After experienced themselves as students that learn through this platform, they can figure out how their students feeling to be taught in a fun way. So, hands-on training in enhancing participants' skill conducted for quite a long time than expected until all of the participants were able to create account and input several questions as to their first trial before presenting to facilitators and other participants. Participants assumed that using technology as a professional responsibility and also improve their role in teaching students. Almost all of participants showed a strong willingness to use technology because it was enjoyable to both parties, which directly relates to self-efficacy beliefs (Deci, E., \& Ryan, 2000). It appears that teacher who integrates technologies in classroom will impact the involvement and students' participation. On the other side, participants also showed their threat at the same time, because they become engaged with troubleshooting technology tasks to get into the digital era of education. This is related to previous finding that teachers who professionally participated in many activities are more likely to become effective tech-savvy educators (Becker, H. J., \& Riel, 1999).

To measure learning objectives achievement for participants, facilitators made some kinds of assessment: reflection, discussion, and presentation. These three kinds of assessment have been completed by all participants and we figure out that $10 \%$ of participants need to attend intense classes caused by their very low teaching skills and limited to understand about technology. $60 \%$ of participants were more than ready to implement the result of training in their classroom in their daily routines. The rest of the participants showed their middle capability in using technology, absorb materials and need to evaluate their motivation as a teacher. Teachers in poor inner-city and rural area like Banyumas, Nias face more challenges to integrate technology in their teaching-learning process, caused by the lack of infrastructure support. This current condition supports results in which almost half of the participants were from rural or inner-city schools and reported that they do experience challenges in lack of time, funding, and support (Kleiman, 2000).

\section{CONCLUSION}

To conclude this community service, facilitators realized that to divert into the digital era is not easy. As per said by Becker (1994), teacher teaches in many kind of schools, but they have same characteristics because they have been nurtured and supported by same institution and same treatment as well. It will open equal opportunities for teacher to develop their skills in teaching mediated by technology. The nature of conventional learning is still embedded in every teacher as participants in this

$$
\text { Pendidikan }
$$


training. Most of the participants were encouraged to enhance their skills in practicing platform into classroom activities. They have such a strong motivation as educators to improve their skills to reach more students. The communication skill to explain materials for students needed to be improved. It is seen when they need to do a presentation to explain simple materials as addition, subtraction, division or factors. This training would not be able to be accomplished by a single meeting. That is the reason why the board of GKY Puri Indah and Facilitator assigned this community service as a continuous program that will be held twice in a year. There is a need to do more training to solve the challenges about technology usage to be implemented in their classroom.

\section{REFERENCES}

Author. (1999). Public School Teachers use of Computers and the Internet. Washington, DC.

Becker, H. J., \& Riel, M. M. (1999). Teacher Professional Engagement and ConstructivistCompatible Computer Use.

Becker, H. J. (1994). How exemplary computerusing teachers differ from other teachers: Implications for realizing the potential of computers in schools. Journal of Research on Computing in Education, 26(3), 291-321.

Becker, H. J. (2000). How exemplary computerusing teachers differ from other teachers: Implications for realizing the potential of computers in schools. Contemporary Issues in Technology and Teacher Education, 2, 274293.

Carlson, J. R., \& Zmud, R. W. (1994). Channel expansion theory: A dynamic view of media and information richness perceptions. Academy of Management: Best Papers Proceedings, 280-284.

Carlson, J. R., \& Zmud, R. W. (1999). Channel Expansion Theory and THe Experimental Nature of Media Richness Perceptions. Academy of Management Journal, 42, 153170.
Collier, S, Weinburgh, M., \& Rivera, M. (2004). Infusing technology skills into a teacher education program: Change in students' knowledge about and use of technology. Journal of Technology and Teacher Education, 12(3), 447-468.

Deci, E., \& Ryan, R. (2000). The "what" and "why" of goal pursuits: Human needs and the selfdetermination of behavior. In Psychology Inquiry.

Guerrero, S. M. (2005). Teacher knowledge and a new domain of expertise: Pedagogical technology knowledge. Journal of Educational Computing Research, 33(3), 249-267.

Kleiman, G. M. (2000). Myths and realities about technology in K-12 schools. In The digital classroom: How technology is changing the way we teach and learn (pp. 7-18).

Lizardy-hajbi, K. (2018). Nurturing Leadership Development for the Now and the Next: A Denominational Perspective. Reflective Practice: Formation and Supervision in Ministry, 38(0).

Stefany, S. (2017). LITERASI DIGITAL DAN PEMBUKAAN DIRI: Studi Korelasi Penggunaan Media Sosial Pada Pelajar Remaja di Kota Medan Magister Ilmu Komunikasi, Fakultas Ilmu Sosial Ilmu Politik, Universitas Sumatera Utara . Magister Ilmu Komunikasi, Fakultas Ilmu Sosial Ilmu. Sosioglobal, 2(1), 10-31. Retrieved from http://jurnal.unpad.ac.id/sosioglobal/article/vie w/15268

Stefany, S., \& Prihandini, P. (2017). Interpersonal Communication in Parenting Style Across Generations $(X \& Y)$. 3(6), 321-327. Retrieved from https://www.atlantispress.com/proceedings/icosop-16/25873525

Swain, C., \& Pearson, T. (2001). Bridging the digital divide: A building block for teachers. Learning and Leading with Technology, 18(8), 10-13. 
Prosiding PKM-CSR, Vol. 2 (2019)

e-ISSN: 2655-3570 